\title{
Preparation of Carboxylic Acids from Aldehydes (Including Hydroxylated Benzaldehydes) by Oxidation with Chlorite
}

\author{
BENGTO. LINDGREN and TORSTEN NILSSON
}

Swedish Forest Products Research Laboratory, Box 5604, S-114 86 Stockholm, Sweden

\begin{abstract}
During the oxidation of aldehydes to acids with sodium chlorite, chlorine dioxide is simultaneously formed and may react with starting material and products in undesirable side-reactions. By performing the reaction in the presence of a chlorine scavenger, e.g. sulphamic acid, the formation of chlorine dioxide is avoided, and high yields of the acids from the corresponding aldehydes (even hydroxylated benzaldehydes) are obtained.
\end{abstract}

$\mathrm{T}^{\mathrm{s}}$ he oxidation of vanillin (3-methoxy-4-hydroxybenzaldehyde) with chlorite and with chlorine dioxide has previously been studied by Purves and coworkers, ${ }^{1}$ Sarkanen et $a l .,{ }^{2}$ and Ishikawa et $a l .^{3}$ They obtained complicated. oxidation mixtures from which a few compounds could be isolated in low yields. Neither chlorine dioxide nor chlorite oxidation yielded any vanillic acid.

We reported recently that the chlorite oxidation of vanillin ${ }^{4}$ (as well as of some other phenolic lignin model compounds and some lignin materials ${ }^{5}$ ) is retarded when a chlorine scavenger is added. Further, the reaction is accelerated by chlorine addition. From these observations we concluded that the oxidation proceeds by a chain mechanism with the following propagation reactions:

$$
\begin{gathered}
\mathrm{Cl}_{2}+2 \mathrm{ClO}_{2}^{-} \rightarrow 2 \mathrm{ClO}_{2}+2 \mathrm{Cl}^{-} \\
\text {vanillin }+2 \mathrm{ClO}_{2} \rightarrow \text { products }+\mathrm{ClO}_{2}^{-}+{ }^{1} / 2 \mathrm{Cl}_{2}+\mathrm{H}^{+}
\end{gathered}
$$

(The reaction can also be formulated with hypochlorous acid instead of chlorine.)

The way in which the chain process is initiated was not elucidated, but was suggested to be caused by the chlorine formed by a slow reaction between chlorite and vanillin. This proposal is confirmed in this paper.

\section{RESULTS AND DISCUSSIONS}

According to the proposed mechanism, the chlorite oxidation of vanillin in the presence of a chlorine scavenger should give the reaction products of 
the initial reaction. When such an oxidation was performed with sulphamic acid or resorcinol as scavenger under proper conditions (room temperature, $\mathrm{pH} 3.5)$, vanillic acid was obtained in good yield $(81-84 \%)$. In the experiment with resorcinol addition, 4-chloro-1,3-dihydroxybenzene was formed in almost theoretical amounts. When phenol was used as scavenger, the vanillic acid formed was difficult to isolate from the reaction mixture.

These results indicate that the initiating reaction between chlorite and vanillin gives hypochlorite and vanillic acid. The oxidation probably starts with an attack by a chlorite ion on the protonized aldehyde group:

$\mathrm{R}-\mathrm{CHO} \stackrel{\mathrm{H}^{+}}{\longrightarrow} \mathrm{R}-\mathrm{C}^{+} \mathrm{H}(\mathrm{OH}) \stackrel{+\mathrm{ClO}_{2}^{-}}{\longrightarrow} \mathrm{R}-\mathrm{CH}(\mathrm{OH})(\mathrm{OClO}) \stackrel{-\mathrm{HOCl}}{\longrightarrow} \mathrm{R}-\mathrm{COOH}$

This assumption is supported by the relative reaction rates between different aldehydes (see below) and by the fact that the reaction is catalysed by acids.

Chlorite seems to be a rather selective agent for oxidation of aldehydes to carboxylic acids and it has been used repeatedly for this purpose in the carbohydrate field.6,7 Its use is hampered, however, by the formation of chlorine dioxide. This gas is unpleasant and may cause side reactions which by the above mentioned chain mechanism may predominate as in the oxidation of vanillin. These complications may be avoided by adding a chlorine scavenger.

The synthesis of vanillic acid from vanillin has earlier been carried out by oxidation with silver oxide and by dehydrogenation in alkali hydroxide solution, but no convenient method has been published for the oxidation of hydroxylated benzaldehydes (such as vanillin and $o$-vanillin) to their corresponding acids. Chlorite oxidation in the presence of a scavenger now seems to be a suitable and inexpensive method.

The disagreeable formation of chlorine dioxide was avoided also when the chlorite oxidations of benzaldehyde, cinnamic aldehyde, $p$-nitrobenzaldehyde and cyclohex-3-ene aldehyde were performed in the presence of a scavenger. The corresponding acids were obtained in good yields.

The reaction rate (determined by the chlorite consumption) increased in the order vanillin, benzaldehyde, and $p$-nitrobenzaldehyde, as should be expected for a reaction involving a nucleophilic attack by chlorite, as postulated above.

\section{EXPERIMENTAL}

The sodium chlorite used was technical grade (about $80 \%$ pure). The chlorite concentrations were determined iodometrically. Besides the m.p. determination, all products were identified by their IR and/or NMR spectra.

2-Hydroxy-3-methoxybenzoic acid. To a solution of o-vanillin $(10 \mathrm{mmol})$ and sulphamic acid $(13 \mathrm{mmol})$ in water $(500 \mathrm{ml})$, sodium chlorite $(13.4 \mathrm{mmol})$ in water $(20 \mathrm{ml})$ was added. After $30 \mathrm{~min}$ the solution was extracted with ether. Evaporation of the ether and recrystallisation of the residue from water gave 2-hydroxy-3-methoxy-benzoic acid monohydrate $\left(1.30 \mathrm{~g}\right.$, yield $80 \%$, m.p. $151-152^{\circ} \mathrm{C}$, lit. $\left.151^{\circ} \mathrm{C}\right)$.

Vanillic acid. (a) Sulphamic acid as scavenger. To a solution of vanillin $(98.6 \mathrm{mmol})$ and sulphamic acid $(134 \mathrm{mmol})$ in water $(2 \mathrm{l})$ a solution $(150 \mathrm{ml})$ of sodium chlorite (102 mmol) was added. The precipitate of vanillic acid (13.9 g, 84\%; m.p. $208-211^{\circ} \mathrm{C}$, lit. $211^{\circ} \mathrm{C}$ ) was filtered off after $1 \mathrm{~h}$.

Resorcinol (b) as scavenger. Vanillin (10 mmol) in $t$-butanol $(19 \mathrm{ml})$ and resorcinol (13 $\mathrm{mmol}$ ) in an acetate buffer ( $\mathrm{pH} 3.93$ ) and aqueous sodium chlorite solution ( $12 \mathrm{mmol}$, $13 \mathrm{ml}$ ) were mixed. The precipitate of vanillic acid (yield $50 \%$ ) was filtered off. From the

Acta Chem. Scand. 27 (1973) No. 3 
filtrate, a further amount ( $31 \%$, total yield $81 \%$ ) of vanillic acid was obtained: the flltrate was extracted with methylene chloride and from the extract the fraction soluble in a sodium hydrogen carbonate solution was isolated. The extract fraction soluble in a sodium hydroxide solution contained 4-chloro-1,3-dihydroxybenzene; the yield estimated by NMR was $87 \%$.

Cyclohex-3-ene carboxylic acid. To a mixture of cyclohex-3-ene aldehyde (100 mmol) in a phosphate buffer ( $\mathrm{pH} 3.5,100 \mathrm{ml})$ sodium chlorite $(120 \mathrm{mmol})$ in water $(40 \mathrm{ml})$ was slowly added at $-5^{\circ} \mathrm{C}$. The temperature rose rapidly to $20^{\circ} \mathrm{C}$. After $15 \mathrm{~min}$ the main part of the dioxane was removed by evaporation. The residue was then acidified and extracted with ether from which the acidic product $(13.1 \mathrm{~g})$ was collected as above.

An aliquot $(5 \mathrm{~g})$ of the residue was distilled under nitrogen. The main fraction (138$\left.140^{\circ} \mathrm{C}, 3 \mathrm{mmHg}\right)$ consisted of cyclohex-3-ene carboxylic acid $(4.0 \mathrm{~g}$, yield $80 \%)$ indistinguishable by IR and NMR from an authentic sample.

Cinnamic acid. To a mixture of cinnamic aldehyde $(10 \mathrm{mmol})$ in $t$-butanol $(25 \mathrm{ml})$ and resorcinol (13 mmol) in an acetate buffer $(20 \mathrm{ml}, \mathrm{pH} 3.92)$, sodium chlorite $(12.4 \mathrm{mmol})$ in water ( $18 \mathrm{ml}$ ) was added. After $45 \mathrm{~min}$ the mixture was evaporated in order to remove most of the $t$-butanol and was then extracted with ethyl ether. From the ether solution the acidic fraction ( $1.15 \mathrm{~g})$ was collected as above. It consisted of cinnamic acid contaminated with 4-chloro-1,3-dihydroxybenzene. Sublimation of an aliquot (202 $\mathrm{mg}$ ) of the mixture gave cinnamic acid $(171 \mathrm{mg})$, m.p. $136-137^{\circ} \mathrm{C}$, which corresponds to an over all yield of $72 \%$.

$p$-Nitrobenzoic acid. To a mixture of $p$-nitrobenzaldehyde $(10 \mathrm{mmol})$ in $t$-butanol $(60 \mathrm{ml})$ and resorcinol $(13 \mathrm{mmol})$ in an acetate buffer $(50 \mathrm{ml}, \mathrm{pH} 4)$ an aqueous solution of sodium chlorite (12 mmol, $13 \mathrm{ml}$ ) was added. After $30 \mathrm{~min}$ the mixture was extracted with ether. Evaporation of the ether gave $p$-nitrobenzoic acid, m.p. $241-243^{\circ} \mathrm{C}$, lit. $242^{\circ} \mathrm{C}$, (yield 76 $\%$ ).

Benzoic acid. To a mixture of benzaldehyde $(10 \mathrm{mmol})$ in $t$-butanol $(10 \mathrm{ml})$ and resorcinol (13 mmol) in an acetate buffer $(20 \mathrm{ml}, \mathrm{pH} 3.93)$ a solution of sodium chlorite (12 mmol) in water $(13 \mathrm{ml})$ was added. After $18 \mathrm{~h}$ the reaction mixture was extracted with methylene chloride, from which the acid fraction $\left(0.955 \mathrm{~g}, \mathrm{~m} . \mathrm{p} .85-110^{\circ} \mathrm{C}\right)$ was collected as above. Fractionated sublimation of an aliquot $(100 \mathrm{mg})$ gave benzoic acid $(84.3 \mathrm{mg}$, over-all yield $88 \%$ ), m.p. $124-125^{\circ} \mathrm{C}$.

Acknowledgements. We are grateful to Miss Annette Grünewald and Mr. Örjan Eriksson for valuable experimental assistance and one of us (Torsten Nilsson) thanks Cellulosaindustriens stiftelse för teknisk och skoglig forskning samt utbildning for a scholarship. We also are indebted to Dr. Stan Froehner for linguistic revision of this manuscript.

\section{REFERENCES}

1. Husband, R. M., Logan, C. D. and Purves, C. B. Can. J. Chem. 33 (1955) 68.

2. Sarkanen, K. V., Kakehi, K., Murphy, R. A. and White, H. Tappi 45 (1962) 24.

3. Ishikawa, T., Sumimoto, M. and Kondo, T. J. Jap. Tappi 23 (1969) 117.

4. Lindgren, B. O. Svensk Papperstid. 74 (1971) 57.

5. Lindgren, B. O. and Nilsson, T. Svensk Papperstid. 75 (1972) 161.

6. Jeanes, A. and Isbell, H. S. J. Res. Natl. Bur. Std. 27 (1941) 125.

7. Nevell, T. P. Methods Carbohyd. Chem. 3 (1963) 182.

Received October 11, 1972. 